QUALITY

Volume 8, Nomor 2, 2020, 319-340

\title{
Pendidikan Agama Islam dalam Menumbuhkan Kepribadian Muslim Peserta Didik Boarding School
}

\author{
Aris Syaiful Huda \\ SMA Negeri 1 Jakenan, Pati, Indonesia \\ ariespati9@gmail.com
}

\begin{abstract}
Abstrak
Artikel ini bertujuan untuk mengetahui makna pendidikan agama, makna kepribadian muslim peserta didik dan mengetahui pengalaman dan makna pendidikan agama Islam dalam menumbuhkan kepribadian muslim peserta didik melalui program boarding school di SMK Negeri Jawa Tengah di Pati. Penelitian ini merupakan penelitian lapangan dengan pendekatan kualitatif kategori fenomenologi. Hasil penelitiannya menunjukkan ada 3 klaster tema dari para partisipan. Hasilnya adalah esensi pengalaman digali dari makna yang dilekatkan oleh partisipan atas pengalaman mereka yang mencakup makna tentang kegiatan belajar mengajar pendidikan agama Islam yang menyenangkan, makna kepribadian muslim dengan bertambahnya Iman semakin kuat, dan makna pendidikan agama Islam dalam menumbuhkan kepribadian muslim peserta didik melalui program boarding school dengan selalu beramal shaleh.
\end{abstract}

Kata Kunci: Pendidikan Agama Islam, Kepribadian Muslim, Boarding School 


\begin{abstract}
The purpose of this study was to determine the meaning of religious education, the meaning of Muslim personality of students and to know the experience and meaning of Islamic religious education in fostering Muslim personality of students through the boarding school program at SMK Negeri Jawa Tengah in Pati. This research is a field research with a qualitative approach to the phenomenological category. The results of his research showed that there were 3 theme clusters of the participants. The result is that the essence of experience is extracted from the meaning attached by the participants to their experience which includes the meaning of fun Islamic religious education teaching and learning activities, the meaning of Muslim personality with increasing faith is getting stronger, and the meaning of Islamic religious education in fostering the Muslim personality of students through the boarding program. school by always doing good deeds.
\end{abstract}

Keywords: Islamic Religious Education, Muslim Personality, Boarding School

\title{
A. Pendahuluan
}

Era penuh perkembangan digital, manusia hidup tetap tidak bisa lepas dari pendidikan. Bahkan dalam konsep Islam pendidikan dimulai dari lahir hingga masuk ke liang lahat atau meninggal. Konsep ini sering kita kenal dengan istilah long life education. Tujuan hidup yang akan kita wujudkan juga membutuhkan ilmu yang diperoleh melalui pendidikan. Pendidikan sebagai salah satu dasar yang mempunyai peranan pokok dalam membentuk generasi masa depan yang lebih baik, menjadikan manusia yang berkualitas, berwawasan luas dan bertanggungjawab.

Sekolah yang merupakan institusi yang melakukan proses pendidikan dalam rangka transfer of knowledge, transver of value dan transfer of skill harus mencukupi kebutuhan pelanggannya (masyarakat dan peserta didik). UU nomor 20 Tahun 2003 mengamanatkan bahwa tujuan pendidikan adalah "peserta didik memiliki kekuatan spiritual keagamaan, pengendalian diri, kepribadian, kecerdasan, akhlak mulia serta keterampilan yang diperlukan dirinya, dan juga untuk pengembangan masyarakat bangsa dan Negara”. Keberadaan pendidikan tidak 


\section{Aris Syaiful Huda}

diragukan lagi kiprahnya, dengan adanya pendidikan Agama Islam akan tercipta generasi anak bangsa yang memiliki sumber daya yang berkompeten dan berakhlak mulia (UUSPN, 2003: 16).

Perubahan perilaku sosial sangat cepat bergerak di era abad 21 ini, oleh karena itu kita semua harus mampu beradaptasi dengan segala perubahan keadaan yang terjadi. Berdasarkan meroketnya grafik kenakalan remaja setiap waktu selalu menjadikan problematika anak-anak muda yang cukup kompleks dan serius harus kita perhatikan. Fenomena-fenomena itu dapat kita saksikan dalam berita-berita $\mathrm{TV}$, radio bahkan di sosial media banyak kejadian-kejadian yang sangat bertolak belakang dengan tujuan pendidikan. Kalau kita perhatikan, bahkan jumlah kasusnya semakin bertambah.

Data-data tentang problematika kenakalan remaja merupakan data yang menjadi pukulan telak di dunia pendidikan. Saat ini manusia banyak didominasi oleh kehidupan materi yang hanya mementingkan kehidupan duniawi. Mereka saling bersaing guna meraih pendapatan materi tapi pada saat yang sama membutuhkan hidangan ruhani. Kuatnya keimanan kepada Allah merupakan satu bekal kekuatan luar biasa yang melindungi manusia religius dengan kekuatan ruhaniyah yang dapat menopang dalam menanggung beban hidup, menghindarkannya dari keresahan yang menimpa banyak manusia modern saat ini (M. Utsman Naajati, 1985: 67)

Manusia yang agamis dan religius mempunyai mental yang tangguh dalam menghindar dari sakit jiwa. Seorang psikolog Amerika, Henry Link mengatakan "bahwa seseorang yang religius dan sering mendatangi tempat ibadah memiliki kepribadian yang lebih kuat dan baik dari pada pribadi-pribadi yang tidak beragama atau tidak menjalankan sama sekali suatu ibadah." Sementara itu A.A. Brill juga berkata: "Individu yang benar-benar religius tidak akan pernah menderita sakit jiwa.” (Yusuf Syamsu, 2009: 150) 


\section{Aris Syaiful Huda}

Memahami orang-orang religius dalam pendidikan agama Islam harus mafhum serta melaksanakan ajaran Islam secara kaffah. Hal ini akan menumbuhkan dan membentuk kesehatan mentalnya juga kepribadiannya. Kepribadian yang diharapkan adalah kepribadian yang menunjukkan sebagai seorang muslim yang sejati.

Kepribadian Islam merupakan identitas yang dimiliki seseorang sebagai ciri khas dari keseluruhan tingkah laku yang bersandar pada ajaran Islam yang ditampilkan dalam tingkah laku secara lahiriyah maupun sikap batinnya (Abdul Mujib, 2006: 3). Permasalahanya di masa modern ini kebanyakan peserta didik belajar pendidikan agama Islam namun di dalam dirinya belum tumbuh kepribadian muslim. Masih banyak perilaku mereka yang belum optimal dalam ibadah dan akhlaknya. Mulai dari cara mereka berpakaian yang masih mengikuti mode atau trend yang sedang berkembang, cara bergaul dengan sesama yang mengesampingkan haqqul adami dan juga shalat mereka masih sering ditinggalkan. Atau bahkan mereka sudah rajin shalat namun belum membawa pada aplikasi perbuatannya karena masih selalu berbuat maksiat, padahal Allah SWT menjelaskan dalam Al-Qur'an "Bacalah apa yang telah diwahyukan kepadamu, yaitu Al Kitab (Al Quran) dan dirikanlah shalat. Sesungguhnya shalat itu mencegah dari (perbuatan-perbuatan) keji dan mungkar" (QS. Al-Ankabut: 45)

Dengan fenomena-fenomena yang terus berkembang saat ini, peneliti ingin mendapatkan informasi lebih dalam dengan mengadakan studi fenomenologi Pendidikan Agama Islam dalam menumbuhkan kepribadian Muslim peserta didik boarding school di SMK Negeri Jawa Tengah di Pati.

SMK Negeri Jawa Tengah di Pati merupakan salah satu lembaga pendidikan di kabupaten Pati. Sekolah ini sudah memenuhi SNP yang baik, sarana prasarana lengkap. Walaupun sebagai sekolah yang baru, prestasi sudah banyak didapatkan oleh peserta didiknya baik di bidang akademik maupun non akademik bahkan kedisiplinannya sudah dikenal dikalangan masyarakat. SMK Negeri Jawa Tengah di Pati ini adalah salah satu sekolah gratis milik Pemerintah Provinsi Jawa 


\section{Aris Syaiful Huda}

Tengah yang diperuntukkan untuk siswa miskin di wilayah Jawa Tengah yang seluruh peserta didiknya diasramakan (boarding school). Biaya penyelenggaraan Pendidikan seluruhnya digratiskan, seperti seragam, perlengkapan sekolah, konsumsi dan asrama. Dengan sistem boarding school pendidikan dapat dilakukan 24 jam karena ketika mengandalkan jam KBM Pendidikan Agama Islam dalam satu minggu hanya terhitung 3 JPL atau 120 menit dirasa masih sangat kurang untuk membentuk kepribadian muslim peserta didik (M.Supirsa, wawancara, 3 Oktober 2019).

Tujuan penelitian ini adalah untuk mengetahui makna pendidikan agama Islam, makna kepribadian muslim peserta didik dan untuk mengetahui pengalaman dan makna pendidikan agama Islam dalam menumbuhkan kepribadian muslim peserta didik melalui program boarding school di SMK Negeri Jawa Tengah di Pati Tahun Pelajaran 2019/2020.

Penelitian ini termasuk qualitative research kategori fenomenologi, di mana persoalan-persoalan yang diteliti berupa kajian deskriptif analitik yang bersifat fenomenologis. Artinya penelitian ini akan berdiskusi tentang suatu objek kajian dengan memahami inti pengalaman dari suatu fenomena. Qualitative research dengan metode fenomenologis didasarkan pada falsafah fenomenologi, dengan cara peneliti berupaya merumuskan suatu pertanyaan yang kemudian mencari makna dan dianalisis berdasarkan pada pertanyaan "persepsi" partisipan berdasarkan fenomena yang sedang diteliti. Teknik pengumpulan data dilakukan dengan menggunakan teknik observasi, dokumentasi, dan wawancara mendalam dari para informan. Pemilihan informan menggunakan tehnik purposive sampling. Di bagian akhir tehnik analisa datanya menggunakan model Clark Moustakas dengan tahapan, pertama, tahap awal peneliti mendeskripsikan sepenuhnya fenomena yang dialami subyek penelitian, kedua, tahap horizonalization, ketiga, tahap cluster of meaning tahap keempat adalah deskripsi esensi, dan tahap terakhir melaporkan hasil penelitian. 


\section{B. Pembahasan}

\section{Pendidikan Agama Islam}

Pendidikan Agama Islam atau dalam Kurikulum 2013 menjadi Pendidikan Agama Islam dan Budi Pekerti ialah pendidikan membina perilaku, sikap, karakter, kepribadian dan menyampaikan kognitif (pengetahuan) serta ketrampilan peserta didik untuk mengamalkan serta melaksanakan ajaran dalama syari'at Islam, yang minimal dilaksanakan melalui bidang pelajaran di setiap jenjang mulai dari pendidikan dasar, menengah bahkan perguruan tinggi (Kemendikbud: 2013). Penjelasan pendidikan agama Islam oleh pemerintah dengan uraian dalam Kurikulum 2013 (K-13) di atas menitikberatkan kepada konsepsi pendidikan yang menitikberatkan pada penumbuhan karakter dan kepribadian peserta didik. Artinya pendidikan agama tidak hanya semata-mata mengajarkan pengetahuan namun yang lebih pokok adalah mengajarkan nilai yang dapat membentuk kepribadian peserta didik.

Melalui Pendidikan Agama Islam, peserta didik disiapkan secara sadar serta terencana agar mengetahui, mengenal, memahami, menghayati, sampai meyakini dan mengimani, bertaqwa, dan berakhlak shaleh untuk menerapkan ajaran agama Islam berdasarkan Al-Qur'an dan Al-Hadis melalui pendidikan, bimbingan, pengajaran, latihan serta pengalaman-pengalaman hidup sehari-hari (Abdul Majid, 2012: 11).

Menurut al-Ghazali sebagaimana dikutip Fathur Rahman menjelaskan bahwasannya tujuan umum pendidikan Islam terpancar dalam dua sisi, ialah taqarrub kepada Allah SWT dan mendapatkan kepuasan hidup di dunia dan akherat (Fathurrahman, $1986: 24)$.

Sesuai pemaparan di atas, sejumlah tujuan pendidikan Islam sudah sangat jelas tersurat bahwasannya pendidikan Islam disampaikan supaya peserta didik mempunyai kepribadian, watak dan karakter dengan dasar keimanan dan ketaqwaaan kepada Allah serta nilai-nilai perilaku mulia serta selalu diimplementasikan dalam kehidupan sehari-hari. 


\section{Kepribadian Muslim}

Kepribadian dalam bahasa Arab dikenal dengan sebutan "syakhshiyah". Syakhshiyah menurut etimologi bermakna "shifaanun tumayyizu al-asykhasha min ghairihi" artinya sifat atau ciri bawaan yang menjadikan setiap individu berbeda dengan yang lainnya (Abdul Mujib dan Yusuf Mundzakir, 2002: 37). Gordon W. Allport memberikan definisi kepribadian sebagai: "Personality is the dynamic organization within the individual of the psychophysical system that determine his unique adjustment to his environment”. Kepribadian adalah organisasi yang dinamis dalam diri individu yang menentukan penyesuaian uniknya terhadap lingkungannya (Abdul Aziz Ahyadi, 1987 : 63).

Setiap individu yang beragama Islam dinamakan muslim. Muslim adalah orang atau seseorang yang menyerahkan dirinya dengan sungguh-sungguh kepada Allah SWT. Jadi dapat disimpulkan wujud pribadi muslim adalah manusia yang menyerahkan dirinya kepada Allah dengan menggabungkan keterpaduan antara faktor iman, islam dan ihsan

Hasan Al-Bana merumuskan 10 Karakterisik Muslim yang menjadi ciri khas dalam diri seorang muslim (Ismail Nawawi, 2013 : 507) yaitu: aqidah keimanan yang lurus atau selamat (Salimul Aqidah atau Aqidatus Salimah), Ibadah dengan benar (Shahibul-Ibadah), akhlak yang kokoh (Matinul-Khuluq), cara berpikir yang luas (Mutsaqqoful-Fikri), badan yang kuat (Qowiyyul-Jismi), berjuang memerangi hawa nafsu (Mujahaatul-Linafsihi), tertib menggunakan waktu (Harishun-Ala-Waqtihi), teratur dalam berbagai persoalan (Munazhzhamun fi Syuunihi), mempunyai kemampuan usaha sendiri (Qodirun Alal Kasbi), manfaat untuk semua orang (Nafi'un-Lighoirihi).

Kepribadian seorang muslim akan menjadikan seseorang menjadi rahmat untuk diri dan lingkungannya. Perilaku keberagamaannya akan meredakan konflik kekerasan atas nama agama. Muslim yang betul-betul berkepribadian akan menempatkan agama sebagai rahmat bagi seluruh alam. Agama Islam hadir sebagai agama perdamaian dan membawa perdamaian (Saliyo, 2018: 119) Sebagaimana dijelaskan dalam al-Qur'an yang artinya “Dan 
tiadalah Kami mengutus kamu, melainkan untuk (menjadi) rahmat bagi semesta alam” (QS. Al-Anbiya': 107)

\section{Boarding School}

Boarding school termasuk kata yang diambil dari bahasa Inggris boarding artinya asrama dan school artinya sekolah. Dijelaskan di dalam Oxford Dictionary "Boarding School is school where pupils live during the term." (Victoria Bull, 2001: 43). maksudnya adalah: boarding school adalah lembaga pendidikan yang peserta didiknya belajar dan tinggal bersama selama kegiatan pembelajaran.

Kemudian Maksudin juga mengemukakan pendapatnya "Boarding school adalah lembaga pendidikan di mana para siswa tidak hanya belajar, tetapi mereka bertempat tinggal dan hidup menyatu di lembaga tersebut." Boarding school mengkombinasikan tempat tinggal para siswa di institusi sekolah yang jauh dari rumah dan keluarga mereka dengan diajarkan agama serta pembelajaran beberapa mata pelajaran (Maksudin, 2008: 111).

Pendidikan dalam bentuk boarding school ini sebenarnya adalah hasil penggabungan antara sistem pendidikan sekolah umum dengan sistem pendidikan pesantren. Seluruh peserta didik belajar dan mendapatkan pendidikan sehari penuh selama 24 jam. Model pendidikan boarding school ini menawarkan keunggulan yang dinilai dari keseriusan peserta didiknya menjadi manusia yang beriman dan bertakwa kepada Tuhan, serta mampu hidup mandiri dalam masyarakat (Murtadho, 2006: 100).

Pendidikan dengan sistem boarding school berdamapak positif dan memberikan pengaruh yang baik terhadap nilai atau moral siswa karena di dalam boarding school siswa tidak hanya mendapatkan ilmu pengetahuan tetapi juga mendapatkan ilmu keagamaan dan langsung dapat dipraktekkan dalam kehidupannya. 


\section{Temuan Penelitian}

\section{a. Tahap Awal Karakteristik Partisipan}

Pemilihan partisipan dalam penelitian ini adalah peserta didik yang ada di SMK Negeri Jawa Tengah Pati. Populasi dalam penelitian yang dilakukan penulis ini adalah semua peserta didik yang ada di SMK Negeri Jawa Tengah Pati. Sampel dalam penelitian ini yang selanjutnya disebut sebagai partisipan, yaitu peserta didik yang terpilih oleh peneliti. Partisipan dipilih dengan tehnik purposive sampling. Purposive sampling ialah pemilihan sampel dengan pertimbangan tertentu, yaitu partisipan dipilih berdasarkan kriteria dan tujuan penelitian.

Dari satu kelas jumlah peserta didik yang dilakukan pendekatan oleh peneliti, sejumlah 5 partisipan yang dijadikan sampel, dengan pertimbangan telah terjadi saturasi data ternyata sudah tidak ada informasi baru lagi yang dapat diambil. Selain dari partisipan, peneliti juga mengambil partisipan lain dari kepala sekolah, pendidik dan wali siswa. Mereka semua penulis wawancarai sebagai penguat data pengalaman para partisipan.

\section{b. Tahap Horizonalization}

Pada tahap ini, peneliti menginventarisasi pernyataan-pernyataan yang penting yang relevan dengan topik. Pada tahap ini, peneliti harus bersabar untuk menunda penilaian. Dalam tahapan ini berhasil penulis inventarisasi pernyataan-pernyataan penting sebagai bagian dari coding.

\section{c. Tahap Cluster of Meaning}

Hasil penelitian ini diperoleh melalui wawancara mendalam dengan partisipan dan catatan observasi lapangan yang dilakukan pada saat wawancara berlangsung. Dari hasil analisis data, peneliti mendapatkan 3 klaster atau pokok makna pendidikan agama Islam dalam menumbuhkan kepribadian muslim peserta didik Boarding School SMK Negeri Jawa Tengah di Pati. 
Tabel 1. Cluster Tema

\begin{tabular}{ll}
\hline No & Cluster Tema \\
\hline 1 & KBM PAI menyenangkan \\
\hline 2 & Iman semakin kuat \\
3 & Selalu beramal Sholeh \\
\hline
\end{tabular}

Proses analisis data dari setiap klaster tema yang ditemukan, dijelaskan dari uraian setiap tema dengan beberapa kutipan pernyataan partisipan sebagai berikut:

\section{1) KBM PAI Menyenangkan}

Hampir semua partisipan mengatakan bahwa kegiatan belajar mengajar untuk mata pelajaran pendidikan agama Islam dan budi pekerti dilakukan di dalam kelas. Pembelajaran ini juga menarik, menyenangkan dan mudah dipahami. Sebagaimana diungkapkan oleh salah seorang partisipan: "Pengalaman saya selama belajar mapel PAI di SMK Negeri Jawa Tengah di Pati sangat menyenangkan dan menarik karena guru pembimbing mapel tersebut menjelaskan materi secara rinci dan penerapannya di kehidupan sehari-hari." (AF, Wawancara, 24 Oktober 2019)

Salah seorang partisipan juga mengungkapkan bahwa ia senang dengan pelajaran PAI karena diajarkan oleh guru yang sabar dan teliti mendidik anak didiknya sekaligus sorang yang hafidz qur'an, sebagaimana dikatakan:

"Pengalaman saya menerima pelajaran PAI di SMK Negeri Jawa Tengah itu menyenangkan di sana saya mendapatkan materi pembelajaran dari seorang guru sekaligus Hafiz Quran yang amat sabar dan teliti dalam mendidik setiap siswa hanya beliau adalah Bapak Supirsa. Selain dari jam pelajaran tersebut kami juga mendapatkan pelajaran agama dari guru ngaji berupa fiqih, hafalan Quran, tahlil, 
Yasin, dan juga Tilawatil Quran semua pendidikan tersebut diberikan dengan tujuan agar kami dapat menjadi manusia yang lebih baik dari sebelumnya." (FADS)

Setelah mendapatkan materi-materi dalam kegiatan belajar mengajar di kelas. Para partisipan bisa langsung mengamalkan dan menerapkan dalam kehidupan sehari-hari. Kegiatan-kegiatan itu adalah pembiasan-pembiasaa di boarding school karena memang seluruh partisipan tinggal 24 jam di sekolah. Sebagimana pernyataan dari partisipan:

"Implementasi dalam kehidupan di sekolah saya yaitu: teori yang diajarkan ketika KBM, sholat tepat waktu, diadakannya one day one ayat, hafalan al quran setiap hari jum'at pagi, kegiatan keagaman setelah sholat isya', mengharagai dan menghormati orang yang lebih tua dari kita, saling menolong antar teman yang membutuhkan bantuan kita" (UC)

Hampir semua partisipan mengungkapkan kegiatan boarding school SMK Jawa Tengah di Pati mulai bangun tidur sampai kegiatan malam. Dari kegiatan-kegiatan yang dilakukan selama 24 jam di SMK Negeri Jawa Tengah Pati dapat mencapai makna hakekat pendidikan agama Islam bagi peserta didik.

Tabel 2. Ringkasan temuan tema KBM PAI yang menyenangkan

\begin{tabular}{llrl}
\hline No & Tema & Pernyataan Informan \\
\hline 1 & $\begin{array}{l}\text { Materi KBM PAI } \\
\text { di Kelas }\end{array}$ & $\begin{array}{l}\text { pembelajaran PAI secara teori } \\
\text { diberikan oleh guru di dalam } \\
\text { kelas } \\
2\end{array}$ & $\begin{array}{l}\text { PAI } \\
\text { dipahami mudah } \\
\text { pembelajaran pendidikan agama } \\
\text { Islam mudah dipahami }\end{array}$ \\
3 & PAI menyenangkan & $\begin{array}{l}\text { Pengalaman saya selama belajar } \\
\text { mapel PAI di SMK Negeri Jawa } \\
\text { Tengah di Pati sangat } \\
\text { menyenangkan dan menarik }\end{array}$ \\
4 & $\begin{array}{l}\text { Langsung praktek } \\
\text { di Boarding School }\end{array}$ & $\begin{array}{l}\text { Implementasi dalam kehidup di } \\
\text { sekolah saya yaitu: teori yang di } \\
\text { ajarkan ketika kbm, sholat tepat } \\
\text { waktu, diadakannya one day one }\end{array}$ \\
\hline & &
\end{tabular}


juz, hafalan al quran setiap hari
jum'at pagi, kegiatan keagaman
setelah sholat isya', mengharagai
dan menghormati orang yang
lebih tua dari kita, saling
menolong antar teman yang
membutuhkan bantuan kita

\section{2) Iman Semakin Kuat}

Berbagai gambaran yang muncul terkait Iman semakin kuat tergambarkan dalam beberapa tema. Tema ini diantaranya adalah melaksanakan perintah Allah, kontrol diri, husnudzan, Allah mengabulkan semua doa.

Partisipan banyak mengungkapkan bahwa semua kebaikan yang ada dalam materi pelajaran pendidikan agama Islam adalah perintah Allah sebagaimana ungkapan partisipan: "Kita mencoba melaksanakan semua perintah Allah dengan shalat jamaah 5 waktu, kontrol diri dan huznudzan" (AF, Wawancara, 24 Oktober 2019)

Ada pula partisipan yang mengungkapkan dulu sebelum sekolah di SMK Negeri Jateng di Pati masih jarang salat, jarang ngaji sekarang sudah mulai berubah sebagaimana disampaikan partisipan sebagai berikut:

"Di asrama saya lebih sering melaksanakan perintah Allah dengan mengaji daripada dulu sebelum saya masuk SMK Negeri Jateng, dan juga setiap masuk waktu sholat, sekarang saya lebih rajin melaksanakan sholat berjamaah. Saya merasa lebih tenang dan keimanan saya terasa lebih kuat" (ES)

Menjadi orang baik, orang sukses dunia dan sukses akherat butuh sebuah proses. Para partisipan mengungkapkan bahwa ketika pertama kali berada di asrama mereka terasa berat namun lama kelamaan dengan adanya pembiasan-pembiasan akhirnya justru merasakan nikmatnya belajar di SMK Negeri Jawa Tengah di Pati. Seperti dikatakan oleh partisipan:

"Alhamdulilallah, saya awalnya berat berada di sekolah ini karena 
harus bangun pagi, shalat subuh jamaah, baris berbaris, makan bersama, mandi bergantian, kegiatan semuanya diatur. Di sini saya mulai bisa merasakan hidup teratur dan terkontrol, berprasangka baik dengan takdir Allah dan hidup dengan orang lain seperti saudara walaupun sama sekali belum saling kenal kenal karena kami berasal dari wilayah yang berbeda." (GK)

Tabel 3. Ringkasan temuan tema Iman semakin kuat

\begin{tabular}{|c|c|c|}
\hline No & Tema & Pernyataan Informan \\
\hline 1 & $\begin{array}{l}\text { Melaksanakan } \\
\text { perintah Allah }\end{array}$ & $\begin{array}{l}\text { Di asrama saya lebih } \\
\text { melaksanakan pering } \\
\text { dengan mengaji daripada dulu } \\
\text { sebelum saya masuk SMK Negeri } \\
\text { Jateng, dan juga setiap masuk } \\
\text { waktu sholat, sekarang saya lebih } \\
\text { rajin melaksanakan sholat } \\
\text { berjamaah. Saya merasa lebih } \\
\text { tenang dan keimanan saya terasa } \\
\text { lebih kuat. }\end{array}$ \\
\hline 2 & Mengontrol diri & $\begin{array}{l}\text { kita harus bisa mengontrol diri kita } \\
\text { dengan terus semangat belajar dan } \\
\text { beribadah karena kalau bermalas- } \\
\text { malasan itu sama saja mengikuti } \\
\text { hawa nafsu dan syetan... }\end{array}$ \\
\hline 3 & Husnudzan & $\begin{array}{l}\text { Selalu berhuznudzan kepada teman, } \\
\text { guru bahkan husnudzan pada Allah } \\
\text { tidak pernah mengeluh terhadap } \\
\text { yang diberikan Allah. segala } \\
\text { sesuatu pasti ada hikmahnya pak.. }\end{array}$ \\
\hline 4 & $\begin{array}{l}\text { Allah akan } \\
\text { mengabulkan doa } \\
\text { kita }\end{array}$ & $\begin{array}{l}\text { Allah swt maha mendengar. Kita } \\
\text { harus yakin bahwa Allah SWT } \\
\text { selalu mendengar apa doa-doa yang } \\
\text { kita panjatkan, dan yakin bahwa } \\
\text { Allah akan mengabulkannya. }\end{array}$ \\
\hline
\end{tabular}

\section{3) Selalu beramal shaleh}

Hasil wawancara penelitian menunjukkan bahwa hampir semua partisipan memperlihatkan tema muncul terkait selalu beramal shaleh. Tema ini diantaranya hubungan dengan Allah atau hablum min Allah seperti Rajin Shalat dan Baca Qur'an, Rajin Ibadah, dan melakukan perintah Allah dan menjauhi larangannya. Beramal shaleh juga diwujudkan 
dnegan hubungan baik dengan sesama. Diantara tema yang muncul adalah Membantu teman, Sabar, Rela berkorban, dan menghormati yang lebih tua, sebagaimana diungkapkan partisipan: “.....di dalam kehidupan berasrama kami berusaha menjaga prasangka dan di sekolah saya diajarkan jiwa korsa. Jadi saya dan teman-teman saya seperti saudara kandung, sehingga apabila terjadi masalah kami saling membantu" (GK, Wawancara, 24 Oktober 2019)

Rajin salat dan baca Qur'an adalah dua kegiatan yang selalu berdampingan. Para partisipan menganggap kegiatan-kegiatan di SMK Negeri Jawa Tengah di Pati ini telah menumbuhkan kepribadian muslim mereka. Di sekolah ini mereka menjadi lebih rajin salat jamaah dan juga membaca al-Qur'an. Hal ini diungkapakan oleh partisipan:

"Selama di sini sangat banyak perubahan yang ada dalam diri saya, jujur saya jarang sekali membaca al Qur'an di rumah dan sekarang saya semakin semangat dalam membaca Al Qur'an, semakin giat menjalankan sholat jamaah, melaksanakan salat sunah dan menghafal Al-Qur'an.” (AF)

Tabel 4. Ringkasan temuan tema Selalu beramal shaleh

\begin{tabular}{|c|c|c|}
\hline No & Tema & Pernyataan Informan \\
\hline 1 & Membantu teman & $\begin{array}{l}\text {...ketika kita di anugrahi sebagai } \\
\text { manusia yang mepunyai akal dan } \\
\text { pikiran, kita bisa gunakan untuk } \\
\text { membantu orang lain bisa dengan } \\
\text { cara menolong, menolong tidak } \\
\text { hanya dalam memberi uang } \\
\text { apabila kita tidak punya uang kita } \\
\text { pun bisa menolong lewat tenaga }\end{array}$ \\
\hline 2 & $\begin{array}{l}\text { Rajin Shalat } \\
\text { Baca Qur'an }\end{array}$ & $\begin{array}{l}\text { Di asrama saya lebih sering } \\
\text { mengaji daripada dulu sebelum } \\
\text { saya masuk smk jateng,dan juga } \\
\text { setiap masuk waktu sholat,selalu } \\
\text { melaksanakan sholat berjamaah. }\end{array}$ \\
\hline 3 & Sabar & $\begin{array}{lll}\text { “... kita harus sabar dan tabah } \\
\text { menghadapi } & \text { semua } & \text { yang } \\
\text { menimpa kita" } & & \end{array}$ \\
\hline 4 & Rela Berkorban & "Pantang menyerah \\
\hline
\end{tabular}




\begin{tabular}{ll}
\hline & berkorban demi menegakkan \\
& agama islam, menjadi pemberani \\
& terhadap apapun, selagi kita benar \\
& dan tetap berpedoman pada Allah \\
& swt." \\
\hline 5 Hormat kepada yang & "Hormat kepada guru dan orang \\
lebih tua & tua dan menyayangi kepada \\
& sesama adalah bagian dari \\
& meneladani asma-asma Allah. \\
& Orang tua kita di rumah ya orang \\
& tua kandung bapak dan ibu \\
& sedangkan di sini adalah bapak \\
& dan ibu guru" \\
\hline
\end{tabular}

\section{d.Pembahasan Temuan Penelitian}

Pada bagian pembahasan penelitian ini akan di bagi menjadi tiga tema yaitu Kegiatan Belajar Mengajar (KBM) yang menyenangkan, Iman bertambah kuat dan selalu beramal shaleh.

\section{1) KBM PAI Yang Menyenangkan}

Kegiatan Belajar Mengajar yang menyenangkan adalah bagian proses yang sekarang banyak didengungkan oleh pemerintah yaitu gerakan sekolah menyenagkan (GSM). Kampanye GSM ini harus meningkatkan kesadaran seluruh pemangku kebijakan pendidikan (tenaga pendidik, tenaga kependidikan dan peserta didik) untuk membangun sekolah sebagai tempat yang paling nyaman untuk belajar ilmu pengetahuan dan kemampuan skill hidup agar anakanak menjadi pembelajar yang sukses.

Sekolah memenuhi kriteria menyenangkan jika terdapat suasana yang rileks, bebas dari tekanan, aman, menarik, bangkitnya minat belajar, adanya keterlibatan penuh dari siswa. Perhatian terhadap siswa tercurah, lingkungan belajar yang menarik, siswa bersemangat, siswa memiliki perasaan gembira, siswa memiliki konsentrasi tinggi dan lain sebagainya juga bagian yang harus didapatkan oleh seluruh warga sekolah.

Sebagai hal yang pertama yang dipersiapkan dan direncanakan guru 


\section{Aris Syaiful Huda}

dalam proses kegiatan belajar mengajar adalah perangkat pembelajaran. Perencanaan penumbuhan kepribadian muslim dalam PAI dilakukan pada saat pembuatan perencanaan pembelajaran (RPP). Penyusunan rencana pembelajaran dalam bentuk pembuatan perangkat pembelajaran meliputi pembuatan silabus, program tahunan, program semester, keterkaitan KI dan $\mathrm{KD}$, Analisis KKM, rencana pelaksanaan pembelajaran (RPP) serta rancangan penilaian.

Dari pengamatan tersebut, peneliti melihat bentuk implementasi pembelajaran PAI dalam membentuk kepribadian muslim, salah satunya berdoa, hormat pada guru dan toleran terhadap sesama yaitu dengan harapan siswa-siswi mampu menerapkan dalam hidup bermasyarakat.

Untuk mengimplementasikan pembelajaran PAI yang dapat mencapai tujuan perlu sebuah strategi pembelajaran. Desain pembelajaran menyenangkan adalah sebuah program yang digunakan untuk menciptakan lingkungan belajar yang efektif, menerapkan kurikulum, menyampaikan materi, memudahkan proses belajar (Armansyah, 2010: 21. Kegembiraan disini berarti bangkitnya minat, adanya keterlibatan penuh, terciptanya makna, pemahaman, dan nilai yang membahagiakan pada diri siswa.

Menurut Mulyasa, Pembelajaran menyenangkan (Joyfull Intruction) merupakan suatu proses pembelajaran yang didalamnya terdapat suatu keterikatan dan ketertarikan yang kuat antara guru dan siswa, tanpa ada perasaan terpaksa atau tertekan. Dengan demikian sangat perlu diciptakan suasana yang demokratis dan tidak ada beban, baik guru maupun siswa dalam melakukan proses pembelajaran (Harnowo, 2007: 17).

Berdasarkan hasil penelitian di SMK Negeri Jawa Tengah di Pati menunjukkan data yang diberikan partisipan bahwa guru pendidikan agama Islam dalam mengajarkan pelajaran menarik, mudah dipahami dan langsung dikaitkan dengan fenomena kehidupan peserta didik. Langkah selanjutnya peserta didik dapat langsung mengimplementasikan di boarding school atau asrama mereka yang sudah didukung dengan aturan-aturan yang ada. 
Hasil penelitian juga menunjukkan semua partisipan menganggap kegiatan dalam asrama sangat berpengaruh terhadap implementasi pendidikan agama Islam. Kegiatan-kegiatan itu diantaranya Salat berjama'ah, membaca alQur'an, mengaji mandiri dan terpogram setelah salat magrib dan isya' yang berisi hafalan surat-surat pilihan, ngaji fiqih, tajwid, khitobah, rebana kebersihan setiap pagi baik di lingkungan sekolah bahkan masyarakat.

\section{2) Iman Semakin Kuat}

Iman adalah permasalahan terpenting bagi seorang muslim, sebab iman menentukan nasib seorang di dunia dan akherat. Bahkan kebaikan dunia dan akherat bersandar kepada iman yang benar. Dengan iman seseorang akan mendapatkan kehidupan yang baik di dunia dan kebahagiaan akherat serta keselamatan dari segala keburukan dan adzab Allah.

Iman menurut lughah berarti tashdiq (membenarkan). Sedangkan secara istilah syar'i, iman adalah keyakinan dalam hati, perkataan di lisan, amalan dengan anggota badan, bertambah dengan melakukan ketaatan dan berkurang dengan maksiat. (https://id.wikipedia.org/wiki/Rukun_Iman, dikutip 20 Mei 2020).

Keimanan dalam diri manusia selalu berubah-ubah, bisa bertambah dan berkurang. Hal-hal yang bisa mempengaruhi iman seseorang bertambah diantaranya adalah pertama ilmu yang ia miliki. Dengan ilmu manusia bisa mengetahui dan mengenal Allah. Kedua selalu mengingat Allah dengan dzikir dan takut kepada Allah. Ketiga bertafakur dengan segala ciptaan Allah. Keempat selalu melaksanakan kebaikan dan menjauhi larangan Allah dan Rasulnya (Silahuddin, 2016: 2017).

Hasil penelitian menunjukkan bahwa ada perubahan yang dirasakan oleh para partisipan terhadap keyakinan mereka kepada Allah SWT. Hal yang paling mudah dilihat adalah mereka selalu melaksanakan perintah Allah dengan selalu melaksanakan shalat lima waktu.

Mereka banyak merasakan perubahan pada diri mereka sebelum dan sesudah mereka berada di SMK Negeri Jawa Tengah di Pati dan dalam asrama. 
Di dalam asrama sebelum subuh mereka sudah bangun kemudian apel pengabsenan pagi dilanjutkan shalat subuh berjamaah.

Para peserta didik di SMK Negeri Jateng Pati ini saling membantu untuk mengingatkan dan membangunkan jika ada yang masih tertidur di saat waktu salat sudah tiba. Sambil menunggu jamaah dimulai mereka menjadi terbiasa membaca Al-Qur'an. Hal ini dikuatkan dengan hasil observasi lapangan.

Hasil penelitian juga menunjukkan setelah belajar di SMK Negeri Jateng ini, sikap kontrol diri mereka mulai tertata. Mujahadah an-nafs atau pengendalian merupakan sikap, tindakan atau perilaku seseorang secara sadar baik direncanakan atau tidak, untuk mematuhi nilai dan norma sosial yang berlaku di masyarakat. Pengendalian diri merupakan satu aspek penting dalam kecerdasan emosi (emotional quotient). Aspek ini penting sekali dalam kehidupan manusia sebab musuh terbesar manusia bukan berada di luar dirinya, akan tetapi justru berada di dalam dirinya sendiri. Dengan demikian, kemana pun seseorang pergi, maka orang tersebut selalu diikuti oleh "musuh" yang ada dalam dirinya.

Hasil penelitian yang penulis dapatkan terhadap implementasi pendidikan agama dalam menumbuhan kepribadian peserta didik boarding school SMK Negeri Jawa Tengah di Pati adalah peserta didik bersabar dan ikhlas terhadap ketentuan yang Allah berikan, menjauhi sifat iri dan dengki dan selalu berhuznudzan kepada orang lain dan juga kepada takdir Allah SWT., mensyukuri segala nikmat yang diberikan Allah dengan selalu melaksanakan perintahnya dan menjauhi segala larangannya, hidup mereka lebih teratur dengan segala aturan yang ada di SMK Negeri Jawa Tengah Pati.

Hasil penelitian juga menunjukkan mereka tertib bukan hanya karena takut aturan tetapi sudah mulai tumbuh kesadaran bahwa segala gerak mereka dilihat oleh Allah dan dicatat oleh para malaikat. 
3)

\section{Selalu Beramal Shaleh}

Kalau kita memaknai amal saleh secara sederhana berarti perbuatan atau aktivitas yang baik. Muhammad Quraish Shihab juga menjelaskan makna amal saleh sebagai amal yang diterima dan dipuji oleh Allah SWT. (M. Quraish Shihab, 1997, 753).

Oleh karena itu sesuatu dapat dipandang sebagai amal saleh jika ia berfungsi mendatangkan nilai manfaat. Sebaliknya, perbuatan yang menimbulkkan bahaya, tidak dinamakan amal saleh. Dengan demikian, sebagian ulama mengatakan bahwa suatu pekerjaan dapat dikatakan baik, jika ia membawa dampak manfaat dan menolak mudarat. Jadi, tolok ukur suatu amal baik atau tidak adalah terletak pada nilai manfaat atau mudarat yang dikandungnya.

Iman dan amal shaleh selalu berdampingan. Orang beriman belum dikatakan beriman jika keyakinan dalam hati mereka tidak dimanifestasikan dalam perbuatan baik. Perwujudan iman dapat diamati dengan selalu melaksanakan perintah Allah dan menjauhi larangannya, seperti rajin ibadah, dan selalu berbuat baik dengan sesame.

Hasil penelitian menunjukkan para partisipan sudah mengimplementasikan amal shaleh dalam kehidupannya. Diantaranya: membantu teman, rajin shalat dan baca Qur'an, toleransi, sabar, rela berkorban, hormat kepada yang lebih tua. Lebih lanjut para partisipan menunjukan perilaku amal shaleh diantaranya: tolong menolong sesama teman, memiliki sikap tangguh dan pantang menyerah untuk meraih kesuksesan, peserta didik di SMK Negeri Jawa Tengah Pati ini memiliki semangat rela berkorban yang tinggi, penghormatan kepada yang lebih tua, program hormat, salam dan salaman menjadi suatu pembelajaran penumbuhan kepribadian muslim peserta didik yang sangat penting untuk di implementasikan dimanapun kita berada. 


\section{Simpulan}

Makna pendidikan agama Islam di SMK Negeri Jawa Tengah di Pati adalah meningkatnya keimanan dan ketaqwaan peserta didik kepada Allah SWT serta rajin beramal shaleh kepada sesama. Tercapainya makna pendidikan agama Islam di SMK Negeri Jawa Tengah di Pati diawali dengan perencanaan pembelajaran dengan baik. Sesuai klaster tema pertama, pengalaman dalam kegiatan belajar mengajar pendidikan agama Islam yang menyenangkan. Makna Kepribadian Muslim peserta didik dapat dilihat di klaster tema ke dua. Klaster tema ke dua adalah Iman bertambah kuat. Klaster ini telah melahirkan pengalaman peserta didik untuk menjadi pribadi yang dapat meningkatkan keimanan dengan rajin salat berjamaah, rajin baca al-Qur'an dan berdoa karena Allah pasti akan mengabulkan doa hambanya. Pengalaman dan makna pendidikan Agama Islam dalam menumbuhkan kepribadian peserta didik melalui program Boarding School dapat dilihat di klaster tema yang terakhir. Klaster tema ke tiga yaitu selalu beramal shaleh. Karena dengan sistem boarding school peserta didik ataupun partisipan dapat langsung dilihat implementasi hubungan dengan Allah dan sesama manusia dalam kurun waktu 24 jam. Hal ini dapat dilihat dari makna pengalaman peserta didik dalam kehidupan mereka sehari-hari. Mereka saling membantu teman layaknya saudara, kebersamaan dalam semua kegiatan, rajin salat, rajin, baca qur'an, sabar dalam berbagai keadaan dan rela berkorban demi kebaikan. Dari tiga klaster yang telah dikemukakan telihat bahwa kepribadian muslim peserta didik boarding school SMK Negeri Jawa Tengah sudah mulai tumbuh menjadi sebuah kepribadian yang positif dari pendidikan agama Islam.

\section{Daftar Pustaka}

Al-Qur'an dan Terjemahannya. 1971. Departemen Agama RI. Semarang: CV. Toha Putra.

Armansyah. 2010. Strategi Pembelajaran Menyenangkan dengan Humor. Jakarta: PT Bumi Aksara. 
Harnowo. 2007. Menjadi Guru yang Mampu Mengajar Secara Menyenangkan. Bandung: MLC.

https://id.wikipedia.org/wiki/Rukun_Iman dikutip 20 Mei 2020

Majid, Abdul. 2012. Belajar dan Pembelajaran Pendidikan Agama Islam. Bandung: Remaja Rosdakarya.

Maksudin,.2008. Pendidikan Nilai Boarding School di SMPIT Yogyakarta, Disertasi UIN Sunan Kalijaga. Yogyakarta: UIN Sunan Kalijaga.

Mujib, Abdul dan Yusuf Mudzakir. 2002 Nuansa-Nuansa Psikologi Islam. Jakarta: Raja Grafindo Persada.

Mujib, Abdul. 2006. Kepribadian dalam Psikologi Islam. Jakarta: Raja Grafindo Persada.

Murtadho, 2006. Kumpulan Sinopsis Hasil-hasil Penelitian Pendidikan Agama dan Keagamaan, (Program Peningkatan Kualitas Pelayanan Publik: Badan Litbang dan Diklat Departemen RI).

Najati, M. Utsman. 1985. Al-Qur'an dan Ilmu Jiwa. Bandung: Pustaka.

Rahman, Fathur. 1986. Sistem Pendidikan Versi Al-Ghazali. Bandung: Al-Ma'arif.

Saliyo. 2018. Beragama Rahmatan Lil'alamin: Bersama Madzab Psikologi Transpersonal. Yogyakarta: LKiS.

Shihab, Muhammad Quraish. 1997. Tafsir Al-Quran al-Karim: Tafsir Atas Surat- Surat Pendek Berdasarkan Urutan Turunnya Wahyu. Bandung: Pustaka Hidayah.

Silahuddin. 2016. Internalisasi Pendidikan Iman kepada Anak Perspektif Islam, Jurnal didaktika, Vol. 16: 207.

Syamsu, Yusuf. 2009. Mental Hygiene. Bandung: Mastreo.

Undang-undang Sistem Pendidikan Nasional (UU RI No. 20 Tahun. 2003) dan Peraturan Pelaksanaannya. Jakarta: Sinar Grafika.

Victoria Bull (ed), 2001. Oxford: Learner's Pocket Dictionary, Fourth Edition. New York: Oxford University Press. 
Aris Syaiful Huda 